\title{
REGULAR ARTICLE \\ ANTIXENOSIS RESISTANCE IN OKRA ACCESSIONS AGAINST SHOOT AND FRUIT BORER EARIAS VITTELLA (FAB.)
}

\author{
S. ANITHA, N. KARTHIKA \\ Department of Entomology and Horticulture, Faculty of Agriculture, Annamalai University, \\ Annamalai Nagar 608 002, Tamil Nadu, India
}

\begin{abstract}
The present study is to analyse the antixenosis mechanisms of resistance in ten okra accessions against Shoot and Fruit Borer $E$. vittella. With regard to the free choice feeding preference, the accessions IC140880 and Trichi local were not preferred by any larvae even up to $8 \mathrm{~h}$. The fruit damage of Coimbatore local by the larvae in $8 \mathrm{~h}$ was recorded as lowest, in confined condition. The accession IC 282228 fruit was bored up to a length $9.1 \mathrm{~cm}$ by the larvae in $8 \mathrm{~h}$. On studying the oviposition preference, the accessions IC140880 and Trichi local were least preferred by E. vittella adults. The length and breadth and number of trichomes of these accessions were recorded as maximum. It was observed that the fruit length of IC140880 were greater than other accessions whereas Trichi local recorded higher fruit width compared to other accessions. While assessing the Fruit angle to stem, Coimbatore local recorded a higher value followed by Trichi local, IC140880 and IC 218877. The incidence of shoot and fruit borer was high in IC282228. In overall observation, weight and yield of the fruit is high in IC140880 followed by Trichi local.
\end{abstract}

Keywords: Okra, Eariasvitella, Antixenosis, Feeding preference, Ovipositional preference.

\section{INTRODUCTION}

Abelmoschus esculentus L., also known as Okra, is an important vegetable crop cultivated throughout the world [1]. It is grown widely in India [2]. Okra is mainly consumed as a vegetable, raw, cooked or fried. The roots and stems are used for clearing cane juice in preparation of Gur. High iodine content of fruit help in controlling goitre. Okra seeds contain good quality oil and protein. It contains many nutrients and vitamins essential for human [4]. The major problem in cultiation is the pest and insect attacks. One of the important major pest incidence is the spotted bollworms [5, 6]. Earias spp. is a serious pest of okra which attack in all stages of growth leading to heavy yeild loss $[3,7]$. Controlling the pest through various techniques are in practice to reduce the infestation of pest incidence [8]. The present study was conducted with an objective considering the above facts, to study the antixenosis mechanisms of resistance in okra accessions against shoot and fruit borer E. vitella.

\section{MATERIALS AND METHODS}

The experiment is conducted with preliminary and confirmatory field screening of 10 okra accessions at experimental farm of Annamalai University. The experiment was carried out by randomized block design and the accession details were given in table 1 .

\section{Antixenosis mechanisms of resistance Feeding preference of $E$. vittella}

Feeding preference of $E$. vittella assay was conducted with free choice test to assess the resistant accessions. The accessions of tender fruits were kept at equal distance in circular manner, in a metal container $(36 \times 15 \mathrm{~cm})$. Ten, third instar larvae were pre-starved for four hours before the experiment and released in the centre of the metal container. After 1,2,4,6 and $8 \mathrm{~h}$ of release, the numbers of larva settled on the respective accessions were recorded and the same was replicated five times.

Further a no-choice test was also conducted with $4 \mathrm{~h}$, prestarved third instar larvae, released in fruits of respective accessions in individual containers of separately. The length of the fruit eaten (tunnelling) by the larva was measured after $8 \mathrm{~h}$. The same was replicated five times [3].

\section{Ovipositional preference of $E$. vittella}

To find out the ovipositional preference of E. vittella, $45 \mathrm{~d}$ old potted plants of all the accessions of okra were placed in an oviposition cage $(175 \times 175 \times 175 \mathrm{~cm})$ made up of net to perform free choice test. Ten pairs of newly emerged adults were released in to the cage. Once in $24 \mathrm{~h}$, the plants kept in the oviposition cage were observed for eggs and recorded accurately. Number of eggs per accession is calculated and

Received 23 March 2018; Accepted o5 May 2018

*Corresponding Author

\section{S. Anitha}

Department of Entomology and Horticulture, Faculty of Agriculture, Annamalai University, Annamalai Nagar 608 o02, Tamil Nadu, India

Email: anithaento1993@gmail.com

( This article is open access and licensed under the terms of the Creative Commons Attribution License (http://creativecommons.org/licenses/by/4.o/) which permits unrestricted, use, distribution and reproduction in any medium, or format for any purpose, even commercially provided the work is properly cited. Attribution - You must give appropriate credit, provide a link to the license, and indicate if changes were made. 
then most preferred accession for oviposition is identified and these were replicated five times [3].

\section{Bio physical bases of resistance \\ Trichome density}

The known area of Fruit bits was boiled in hot water for 20 min. Then the fruit bits were transferred into $20 \mathrm{ml}$ of ethanol and boiled for $20 \mathrm{~min}$. This process was done to remove the chlorophyll content. $20 \mathrm{ml}$ of latic acid, was added to the fruit bits and boiled for $20 \mathrm{~min}$. The number of trichome hairs were counted by using a compound microscope and expressed in number $\mathrm{cm}^{-2}$. The samples were collected at three different parts of fruit of the same accession and replicated ten times [3, 9].

\section{Length and breadth of the trichome hairs}

The length and breadth of the trichome hairs were measured by taking thin fruit sections of all the accession after processing the fruit bits as above mentioned method. The samples were collected at three different parts of fruits of the same accession and replicated ten times. A measurement is done by using micrometer [3].

\section{Fruit length, fruit width and fruit angle}

Randomly selected 20 fruits were harvested from each accession and fruit length and fruit width is measured by tracing with the help of a graph paper. The mean angle between the fruit and stem/branch is measured by using a protractor [3].

\section{Statistical analysis}

The data gathered are statistically analysed using IRRISTAT software and the critical difference values were arrived.

\section{Results}

In free choice test, the larvae were allowed to select the fruits of accessions and when observed for feeding, the accessions Trichi local and IC 140880 were not preferred by any larvae even up to $8 \mathrm{~h}$ compared with the other accessions. In confined condition, accession Coimbatore local is (Table. 2) recorded lowest length of fruit damage by the larvae in $8 \mathrm{~h}(1.4 \mathrm{~cm})$. The accession IC 282228 fruit was bored up to a length $9.1 \mathrm{~cm}$ (Table. 2) by the larvae in $8 \mathrm{~h}$. On studying the oviposition preference, the accessions Trichi local (12) and IC140880 is 12.4 (Table. 2) were least preferred by $E$. vittella adults when compared to other accessions. These accessions recorded maximum number (99.6), length $442 \mu$ and breadth $24.80 \mu$ (Table. 3) of trichomes. It was observed that the fruits length of IC140880 (14.6) were greater than other accessions whereas Trichi local $(7 \mathrm{~cm})$ (table 4$)$ recorded higher fruit width than other accessions. While assessing the Fruit angle to stem, Coimbatore local $\left(12.8^{\circ}\right)$ (table 4$)$ recorded a higher value followed by Trichi local, IC140880 and IC 218877. The shoot and fruit borer incidence was high in IC282228. In overall observation, weight and yield of the fruit is high in IC140880 followed by Trichi local (table 5 ).

Table 1: Pest incidence and fruit characters

\begin{tabular}{llllll}
\hline S. No. & Name of the accession & Pest incidence & Fruit colour & Fruit tip & Fruit orientation \\
\hline 1 & Trichi local & Nil & Light green & Blunt & Erect \\
2 & Coimbatore local & Nil & Yellowish green & Pointed & Erect \\
3 & IC218877 & Nil & Pinkish green & Pointed & Erect \\
4 & IC111532 & Low & Light green & Blunt & Erect \\
5 & IC140880 & Nil & Light green & Pointed & Slightly falling \\
6 & IC282226 & Moderate & Yellowish green & Pointed & Erect \\
7 & IC282227 & Moderate & Dark green & Blunt & Erect \\
8 & IC282228 & High & Light green & Pointed & Erect \\
9 & IC282229 & Nil & Light green & Pointed & Erect \\
10 & IC282233 & Moderate & Light green & Pointed & Intermediate \\
\hline
\end{tabular}

Table 2: Feeding and oviposition preferences of $E$. vittella towards fruits of okra accessions

\begin{tabular}{|c|c|c|c|c|}
\hline \multirow{2}{*}{$\begin{array}{l}\text { S. } \\
\text { No. }\end{array}$} & \multirow{2}{*}{$\begin{array}{l}\text { Name of the } \\
\text { accession }\end{array}$} & \multicolumn{2}{|l|}{ Larval feeding preference } & \multirow{2}{*}{$\begin{array}{l}\text { Adult oviposition preference } \\
\text { No. of eggs/plant }\end{array}$} \\
\hline & & $\begin{array}{l}\text { No. of the larvae preferred } \\
\text { after } 8 \mathrm{~h} \text { (Free choice) }\end{array}$ & $\begin{array}{l}\text { Tunnel length in } 8 \mathrm{~h} \\
\text { (cm) (No choice) }\end{array}$ & \\
\hline 1 & Trichi local & $0(0.00)^{\mathrm{a}}$ & $3.34(10.522)^{b}$ & $12(13.908)^{\mathrm{a}}$ \\
\hline 2 & Coimbatore local & $1.6(7.174)^{b}$ & $1.4(6.696)^{\mathrm{a}}$ & $14.2(21.302)^{\mathrm{b}}$ \\
\hline 3 & IC218877 & $1.8(7.543)^{\mathrm{b}}$ & $3.5(10.761)^{b}$ & $15.2(22.461)^{\mathrm{c}}$ \\
\hline 4 & IC111532 & $2.6(9.237)^{\mathrm{c}}$ & $4(11.509)^{\mathrm{cd}}$ & $15.8(22.786)^{\mathrm{cd}}$ \\
\hline 5 & IC140880 & $\mathrm{O}(0.00)^{\mathrm{a}}$ & $1.6(7.214)^{\mathrm{a}}$ & $12.4(14.141)^{\mathrm{a}}$ \\
\hline 6 & IC282226 & $3.2(10.287)^{\mathrm{cd}}$ & $4.5(12.233)^{\mathrm{c}}$ & $19.2(23.733)^{c}$ \\
\hline 7 & IC282227 & $2.6(9.237)^{c}$ & $4.42(12.125)^{\mathrm{c}}$ & $22.6(25.095)^{\mathrm{d}}$ \\
\hline 8 & $\mathrm{IC} 282228$ & $4.6(12.367)^{\mathrm{e}}$ & $9.1(17.557)^{\mathrm{e}}$ & $41.6(29.448)^{\mathrm{d}}$ \\
\hline 9 & IC282229 & $3.46(10.752)^{\mathrm{d}}$ & $7.2(15.557)^{\mathrm{d}}$ & $25(25.252)^{\mathrm{e}}$ \\
\hline 10 & IC282233 & $3.6(10.912)^{\mathrm{d}}$ & $6.4(14.610)^{\mathrm{d}}$ & $27.4(26.276)^{\mathrm{f}}$ \\
\hline & $\mathrm{CD}(\mathrm{p}=0.05)$ & 1.266 & 1.031 & 0.975 \\
\hline
\end{tabular}

Each value is a mean of five replications, values in parentheses are arc sine transformed 
Table 3: Trichome density on the fruit surface of the selected okra accessions

\begin{tabular}{lllll}
\hline S. No. & Name of the accession & Fruit length (cm) & Fruit width (cm) & Fruit angle (o) \\
\hline 1 & Trichi local & $13.5(21.542)^{\mathrm{ab}}$ & $7(15.322)^{\mathrm{a}}$ & $29.6(32.959)^{\mathrm{b}}$ \\
2 & Coimbatore local & $12.8(20.997)^{\mathrm{b}}$ & $6.6(14.929)^{\mathrm{ab}}$ & $32.2(34.568)^{\mathrm{a}}$ \\
3 & IC218877 & $10.25(18.672)^{\mathrm{d}}$ & $3(9.951)^{\mathrm{b}}$ & $28.8(32.456)^{\mathrm{b}}$ \\
4 & IC11532 & $10.05(18.463)^{\mathrm{d}}$ & $4.3(12.011)^{\mathrm{bc}}$ & $20.71(27.068)^{\mathrm{e}}$ \\
5 & IC140880 & $14.6(22.462)^{\mathrm{a}}$ & $6.2(14.456)^{\mathrm{bc}}$ & $28.52(32.274)^{\mathrm{b}}$ \\
6 & IC282226 & $14.58(22.446)^{\mathrm{a}}$ & $4.43(12.147)^{\mathrm{d}}$ & $24.53(29.688)^{\mathrm{c}}$ \\
7 & IC282227 & $12.76(20.923)^{\mathrm{b}}$ & $5.43(13.473)^{\mathrm{cd}}$ & $25(30.000)^{\mathrm{c}}$ \\
8 & IC282228 & $12.58(20.923)^{\mathrm{b}}$ & $3.4(10.605)^{\mathrm{de}}$ & $22.43(28.270)^{\mathrm{d}}$ \\
9 & IC282229 & $11.88(20.162)^{\mathrm{bc}}$ & $3.5(10.638)^{\mathrm{de}}$ & $23.59(29.063)^{\mathrm{cd}}$ \\
10 & IC282233 & $10.75(19.130)^{\mathrm{cd}}$ & $5.3(13.340)^{\mathrm{e}}$ & $20.76(27.108)^{\mathrm{e}}$ \\
& CD $(\mathrm{p}=0.05)$ & 1.402 & 1.791 & 1.140 \\
\hline
\end{tabular}

Each value is a mean of ten replications

Table 4: Biophysical bases of resistance in okra accession

\begin{tabular}{lllll}
\hline S. No. & Name of the accession & $\begin{array}{l}\text { Trichome density } \\
\text { No. } \mathbf{c m}^{-\mathbf{2}}\end{array}$ & Trichome length $(\boldsymbol{\mu})$ & Trichome breath $(\boldsymbol{\mu})$ \\
\hline $\mathbf{1}$ & Trichi local & $99.6(86.931)^{\mathrm{a}}$ & $442(21.20)^{\mathrm{a}}$ & $24.80(29.868)^{\mathrm{a}}$ \\
$\mathbf{2}$ & Coimbatore local & $96.6(79.374)^{\mathrm{b}}$ & $367.167(19.161)^{\mathrm{c}}$ & $14.90(26.730)^{\mathrm{b}}$ \\
$\mathbf{3}$ & IC218877 & $92.2(73.782)^{\mathrm{c}}$ & $345.500(18.588)^{\mathrm{d}}$ & $11.90(18.013)^{\mathrm{h}}$ \\
$\mathbf{4}$ & IC111532 & $90.5(72.048)^{\mathrm{c}}$ & $221.767(14.892)^{\mathrm{c}}$ & $12.90(23.682)^{\mathrm{e}}$ \\
$\mathbf{5}$ & IC140880 & $99.5(86.628)^{\mathrm{a}}$ & $392.833(19.820)^{\mathrm{b}}$ & $14.60(25.682)^{\mathrm{cd}}$ \\
$\mathbf{6}$ & IC282226 & $88.2(69.909)^{\mathrm{d}}$ & $296.400(17.216)^{\mathrm{g}}$ & $18.60(25.549)^{\mathrm{c}}$ \\
$\mathbf{7}$ & IC282227 & $82.4(67.195)^{\mathrm{e}}$ & $311.200(17.641) \mathrm{f}$ & $12.20(20.444)^{\mathrm{g}}$ \\
$\mathbf{8}$ & IC282228 & $74.2(44.312)^{\mathrm{h}}$ & $234.600(15.317)^{\mathrm{h}}$ & $11.20(19.881)^{\mathrm{g}}$ \\
$\mathbf{9}$ & IC282229 & $70.6(57.165)^{\mathrm{g}}$ & $312.400(17.675)^{\mathrm{f}}$ & $13.50(21.557)^{\mathrm{f}}$ \\
$\mathbf{1 0}$ & IC282233 & $48.8(59.473)^{\mathrm{f}}$ & $323.833(17.995)^{\mathrm{e}}$ & $13.10(24.426)^{\mathrm{de}}$ \\
\hline
\end{tabular}

Each value is a mean of twenty replications.

Table 5: Biophysical bases of resistance in okra accession

\begin{tabular}{llll}
\hline S. No. & Name of the accession & Fruit weight per plant & Fruit yield per plant \\
\hline $\mathbf{1}$ & Trichi local & $20.36(26.827)^{\mathrm{a}}$ & $324.33(17.972)^{\mathrm{a}}$ \\
$\mathbf{2}$ & Coimbatore local & $18.16(25.228)^{\mathrm{ab}}$ & $293.33(17.126)^{\mathrm{a}}$ \\
$\mathbf{3}$ & IC218877 & $8.43(16.879)^{\mathrm{b}}$ & $200.00(14.139)^{\mathrm{ab}}$ \\
$\mathbf{4}$ & IC111532 & $8.03(16.413)^{\mathrm{c}}$ & $266.66(16.247)^{\mathrm{ab}}$ \\
$\mathbf{5}$ & IC140880 & $19.03(26.084)^{\mathrm{c}}$ & $320.00(17.883)^{\mathrm{ab}}$ \\
$\mathbf{6}$ & IC282226 & $14.26(22.190)^{\mathrm{d}}$ & $246.66(15.705)^{\mathrm{bc}}$ \\
$\mathbf{7}$ & IC282227 & $11.23(19.669)^{\mathrm{d}}$ & $273.33(16.532)^{\mathrm{cd}}$ \\
$\mathbf{8}$ & IC282228 & $10.56(18.966)^{\mathrm{e}}$ & $140.00(11.725)^{\mathrm{d}}$ \\
$\mathbf{9}$ & IC282229 & $9.30(17.751)^{\mathrm{ef}}$ & $190.00(13.781)^{\mathrm{d}}$ \\
$\mathbf{1 0}$ & IC282233 & $13.33(21.415)^{\mathrm{f}}$ & $183.33(13.525)^{\mathrm{e}}$ \\
& CD $(\mathrm{p}=0.05)$ & 1.156 & 1.751 \\
\hline
\end{tabular}

Each value is a mean of five replications

\section{DISCUSSION}

The accession Trichi local was least preferred by E. vittella. Parentage of this accession is IC140880 and Coimbatore Local. Wild relatives or their derivative was reported to possess resistance against fruit worm, H. armigera [10]. With regard to Fruit feeding preference of $E$. vittella larvae, the accession Trichi local and $\mathrm{IC} 140880$ was not preferred by larvae up to $8 \mathrm{~h}$ and the same trend is observed in no choice condition also. The oviposition preference of $E$. vittella female moths least preferred the accession IC140880 and Trichi local on which only 12 eggs were laid. These were followed by accession Coimbatore local. This may be possibly due to the wild origin that possesses insect and disease resistance [11]. Accession IC282228 was most preferred host for oviposition. With reference to density of trichomes and their length and breadth, among the accessions, Trichi local and Coimbatore local had maximum number of trichomes and these accession were least preferred by $E$. vittella larvae in both free choice and no choice test $[3,12]$. Halder et al. [9] also reported that a significant negative correlation was observed between trichome density and borer incidence. Further, high trichome density might be imparting the physical barrier for the borer rendering their non-preference over the low trichome genotypes. 
Feeding preferences of $E$. vittella towards fruits of okra accessions
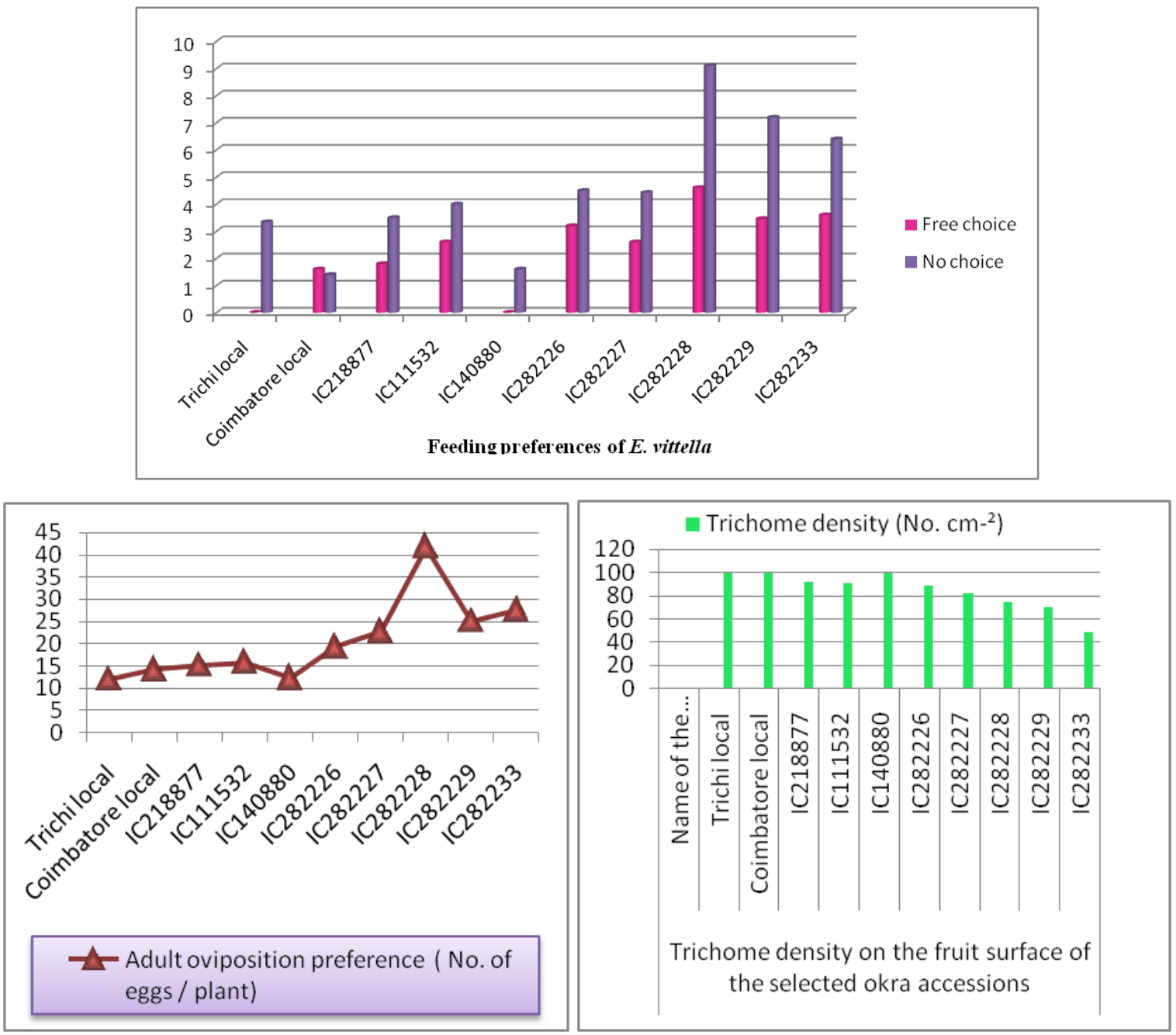

Trichome density on the fruit surface of the selected okra accessions

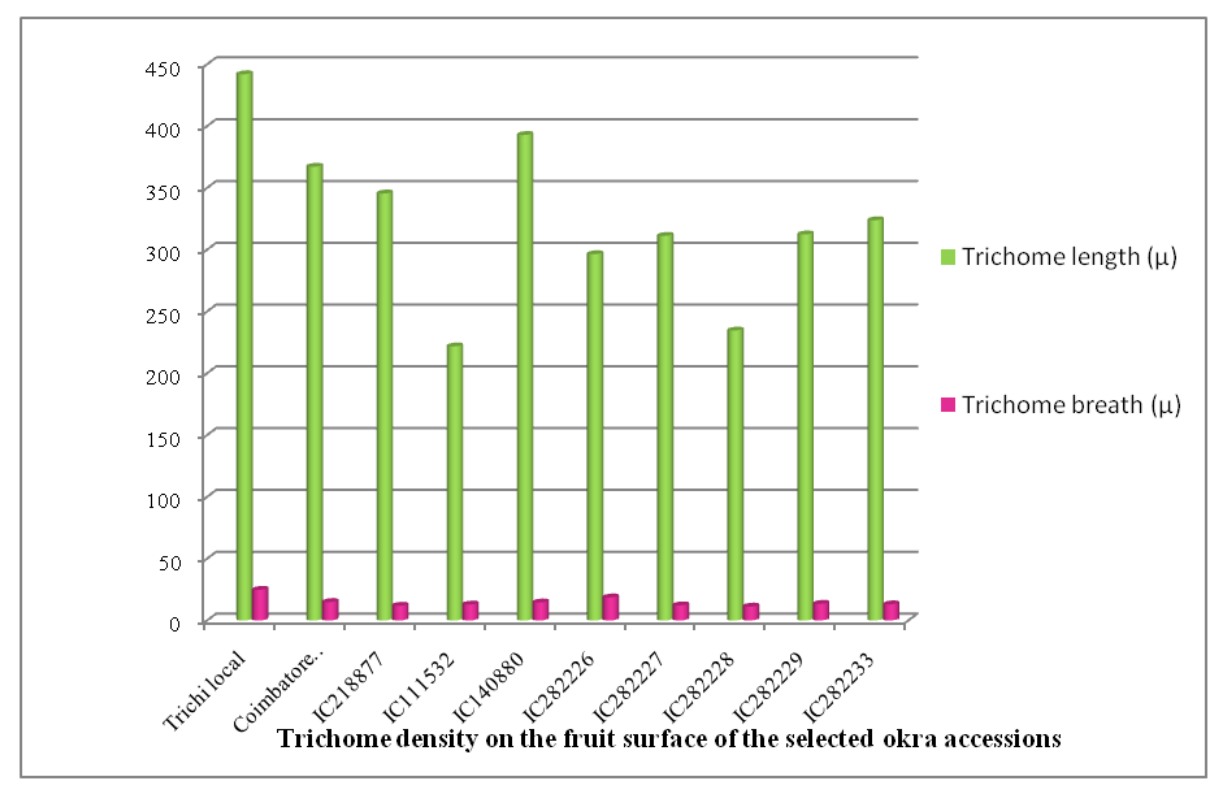


Biophysical bases of resistance in okra accession
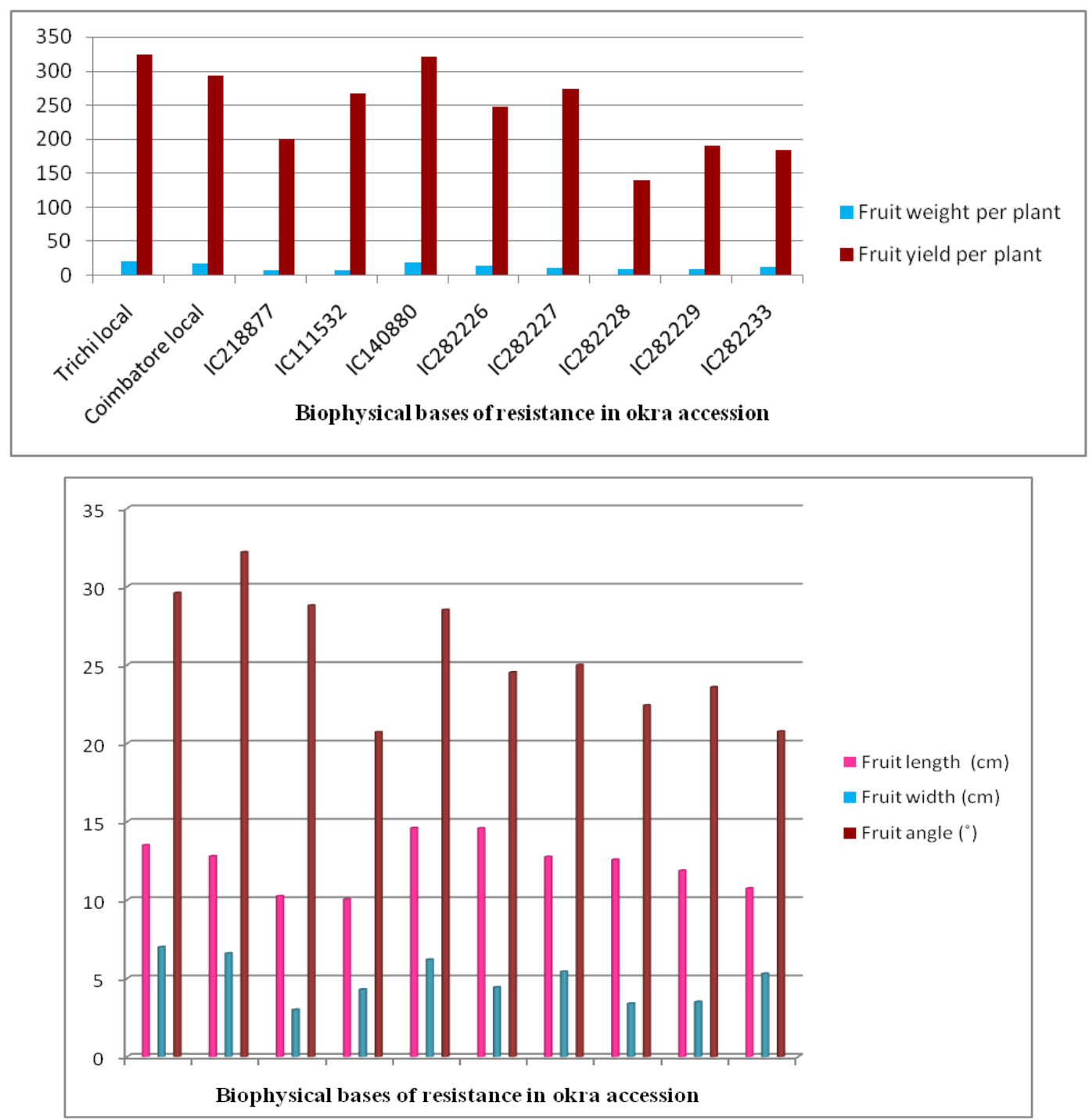

Sharma and Singh [14] reported a significant negative correlation between trichome density and borer infestation in okra. Similar observations were also documented by Halder et al. [15] where in significant negative correlation existed between trichome density in pods and pod borer infestation and damage severity in mungbean. Regarding fruit characters, fruit length of IC282228 was greater; fruit angle is recorded higher value in Coimbatore local and fruit width of Trichi local was greater than other accessions. Lengthy fruits were found more suitable for damage by Earias as they harboured more larvae/fruit. Present study related with Halder and Srinivasan [16] reported similar finding on Maruca infesting cowpea and also found that pod infestation was higher in genotypes that had highest pod length than other genotypes. The influences of host physical property on the degree of infestation were reported by Kamakshi and Srinivasan [17]. In overall observation, weight and yield of the fruit is high in IC 282228 followed by Trichi local.

\section{CONCLUSION}

It is concluded that, the accession Trichi local and IC 140880 was least preferred by E. vittella. Further, repeated field and glasshouse evaluations are necessary.
Only after determining the resistant potentials by repeated evaluation, a promising accession could be suggested for large scale cultivation. Many local cultivars and wild species are resistant against the pest. We must undergo detailed and repeated research in the field condition and recommend to farmers.

\section{REFERENCES}

1. Memon AJ, Abro GH and Syed TS. 2004. Varietal Resistance of Okra against Earias spp. Journal of Entomology, 1:1-5.

2. NHB. 2005. Horticulture Information Service, National Horticultural Board, Gurgaon, pp 55-56.

3. Muthukumaran N and Ganesan P. Antixenosis resistance in okra and their hybrid derivatives against shoot and fruit borer Earias vittella (Fab.). Journal of Entomology and Zoology Studies 2017;5: 1884-1887.

4. Aykroyd WR. Indian Council of Medical Research, Special Report Ser. No. 42, 6th Edition, 1963, 32.

5. Srinivasa Rao N, Rajendran R. Joint action potential of neem with other plant extracts against the leaf hopper Amrasca devastance on okra. Pest Management and Economic Zoology. 2003;10:131-131. 
6. Suman CL, Wahi SD, Jaganmohan N. Distribution pattern of okra shoot and fruit borer (Earias vittella Fab.) under natural condition. Indian Entomology. 1984;45:362-364

7. Atwal AS, Dhaliwali GS. Agricultural pests of south Asia and their management. Kalyani publishers, New Delhi, India. 2005, 280.

8. Wiseman GR, Amin R, Rice WA, Tahir MB. Methods: Manual soils laboratory, Barani Agricultural Research and Development Project. Pakistan Agricultural Research Council, Pakistan. 1990;30-33.

9. Halder J, Sanwal SK, Rai AK, Rai AB, Singh B, Singh BK. Role of physic-morphic and biochemical characters of different okra genotypes in relation to population of okra shoot and fruit borer, Earias vittella (Noctuidae: Lepidoptera). Indian Journal of Agricultural sciences. 2015;85: 278-82.

10. Sankhyan S, Verma AK. Field screening for resistance against the fruit borer Helicoverpa armigera (Hubner) (Lepidoptera: Noctuidae). Pest management in Economic zoology. 1997;5: 107-111.

11. Kalloo G. Genetics improvement of tomato: Monographs on Theoretical and Applied Genetics, Springer-Verlag, Berlin. 1991;14:358.
12. Kumbhar TT, Kokate AS, Dumbre AD. Studies on the varietal resistance in okra (Abelmoschus esculentus L. Moench) to shoot and fruit borer (Earias spp.). Maharashtra Journal of Horticulture, 1991;5: 78-82.

13. Sharma BN, Singh S. Biophysical and biochemical factors of resistance in okra against shoot and fruit borer, Indian Journal of Entomology. 2010;72: 212-6.

14. Halder J, Srinivasan S, Muralikrishna T. Role of various biophysical factors on distribution and abundance of spotted pod borer, Maruca vitrata (Geyer) in mung bean. Annals of Plant Protection Sciences. 2006;15: 49-51.

15. Halder J, Srinivasan S. Varietal screening and role of morphological factors on distribution and abundance of spotted pod borer, Maruca vitrata (Geyer) on cowpea. Annals of Plant Protection Sciences. 2011;19: 71-4.

16. Kamakshi N, Srinivasan S. Influence of certain biophysical factors on incidence of pod borer complex inselected genotypes of field bean Annals of Plant Protection Sciences. 2008;16: 407-9. 